\title{
Temporal Changes in Reef Community Structure at Bintan Island (Indonesia) Suggest Need for Integrated Management ${ }^{1}$
}

\author{
Loke Ming Chou, ${ }^{2}$ Danwei Huang, ${ }^{2,3,4}$ Karenne P. P. Tun, ${ }^{2}$ Jeffrey T. B. Kwik, ${ }^{2}$ \\ Ywee Chieb Tay, ${ }^{2}$ and Angie L. Seow ${ }^{2}$
}

\begin{abstract}
Reefs in Southeast Asia, such as those in Indonesia's Riau archipelago, are among the most diverse habitats in the sea, but limited baseline data pose a severe challenge for their conservation. Here, we surveyed five reef sites along the northern coast of Bintan Island to determine the most recent condition of the benthic and fish communities. Fourteen years of resort development on the island have elapsed since the last survey in 1993. Using several diversity measures to compare the reefs then and in 2007, we found that abundances of hard corals and fish remained high (average of $>50 \%$ coral cover and $>0.7 \mathrm{fish} / \mathrm{m}^{3}$ ), but taxonomic richness was compromised. The most common taxa now account for greater proportions of fish counts at all sites and of coral cover at three of four comparable sites. These shifts in coral and fish assemblages may be explained by freshwater influences and development along the north coast of Bintan Island. Because the local community and tourism industry still rely heavily on the reefs, we advocate implementing a comprehensive, integrated coastal management plan that mitigates further reef declines and promotes sustainable use.
\end{abstract}

The "Coral Triangle," situated in the Indo-West Pacific, harbors the world's richest assemblages of reef fishes and corals (Ekman 1953, Briggs 1999, 2000, Allen 2000, Veron 2000, Spalding et al. 2001, Allen and Werner 2002, Carpenter and Springer 2005). Unfortunately, habitats in and around that region have been threatened by a plethora of human activities, leading to biodiversity loss and ecosystem collapse (Morton and Blackmore 2001, Bruno and Selig 2007; see also Hughes et al. 2003, Bellwood et al. 2004, Worm et al. 2006, Hoegh-Guldberg et al.

\footnotetext{
${ }^{1}$ Manuscript accepted 29 January 2009.

${ }^{2}$ Department of Biological Sciences, National University of Singapore, 14 Science Drive 4, Singapore 117543 , Singapore.

${ }^{3}$ Scripps Institution of Oceanography, University of California, San Diego, 9500 Gilman Drive, La Jolla, California 92093-0208.

${ }^{4}$ Corresponding author (e-mail: huangdanwei@nus .edu.sg).
}

Pacific Science (2010), vol. 64, no. 1:99-111

doi: 10.2984/64.1.099

(C) 2010 by University of Hawai'i Press

All rights reserved
2007). A major challenge for the mitigation of reef destruction is the lack of quantitative data on the diversity of these habitats, especially in Southeast Asia (Burke et al. 2002). Nevertheless, there exist agencies and tourism developers that are concerned with the effects of declining reef health on their communities and businesses, thereby taking steps to alleviate this problem (White and Vogt 2000, Tun et al. 2004; e.g., Allen and Werner 2002, Singleton et al. 2002).

In 1993, Bintan Resort Management, Singapore, commissioned a biodiversity assessment study of northern Bintan Island in the Riau archipelago for the purpose of establishing baseline conditions to support the formulation of coastal management guidelines (Chou et al. 1993) (Figure 1). The coral reef community was surveyed and several areas were found to be very diverse, with many habitats recommended for high conservation priority within a coastal area management plan. In particular, two areas had high diversity of corals and fish (hard coral: $35-57 \%$ cover, 23-38 genera per site; fish: 28-58 species per site): between Pulau [= Island] Rawa and Tanjung [= Cape] Sading and between 


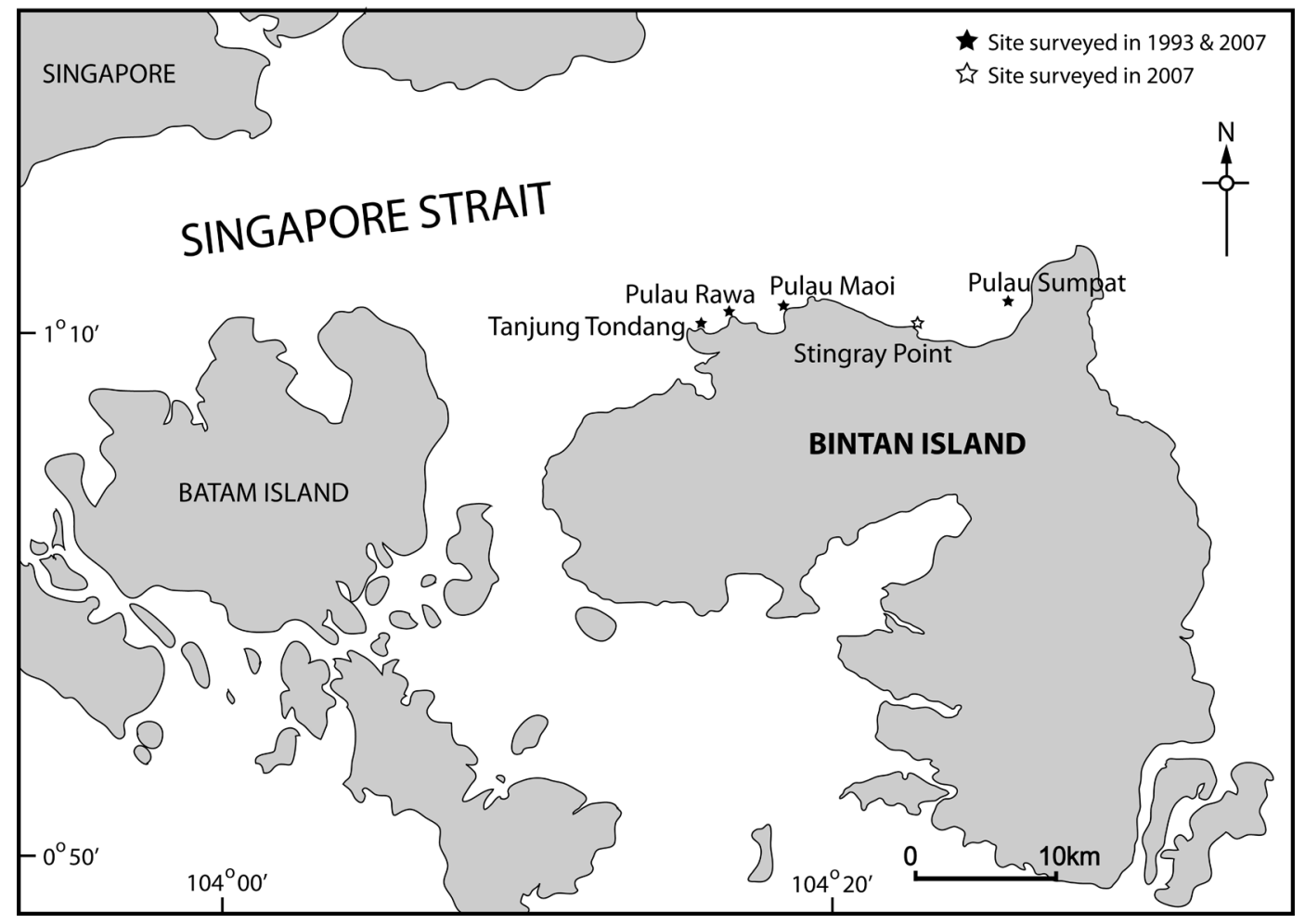

FIGURE 1. Location map of northern Bintan Island, Indonesia, showing five surveyed sites in this study.

Sungai $[=$ River $]$ Penguda and Black Rock. Other recommendations for the coastal zone include the conduct of environmental impact assessment (EIA) before all development projects in the coastal zone, minimizing effects of sedimentation, and controlling the visitorship of more diverse reef communities. Despite impact minimization efforts from various development projects, however, no comprehensive integrated coastal management plan was implemented.

After the 1993 assessment, some data on Bintan Island's fish richness were collected through Conservation International's Rapid Assessment Program-304 species in total (Allen 2001). The reefs of several small islands near Batam Island (adjacent to the west of Bintan) were surveyed by the Research Centre for Oceanography, Indonesia Institute of Science (Nontji 2004). However, no tar- geted biodiversity assessment of the resort areas in Bintan has been carried out; the impact of coastal development on its reefs is unknown. To address this, the present study was undertaken to evaluate variations in the reef community along the northern coast of the island during the last $14 \mathrm{yr}$.

Bintan Island is located within the Singapore Strait, which is part of the Malacca Straits that provide the northernmost connection between the South China Sea and Indian Ocean (Chua et al. 2000). In recent geological time, an average transport of 0.13 Sv $\left(=10^{6} \mathrm{~m}^{3} \mathrm{sec}^{-1}\right)$ flows annually through this channel with the aid of the monsoondriven east-to-west current, forming about $10 \%$ of the Indonesian Throughflow (Pang and Tkalich 2003, Humphries and Webb 2008). Such a connection is of immense biological interest because sea habitats along the 
Malacca Straits serve as the most equatorial interface for gene flow between marine populations in the Indian Ocean and South China Sea (Ge and Sun 2001, Leaw et al. 2001, Casey et al. 2004, Lourie and Vincent 2004, Reid et al. 2006, Hoeksema 2007). In fact, this channel may not have been submerged until the last interglacial period $(\sim 127,000 \mathrm{yr}$ ago), and only subsequent changes in the water level (through the Last Glacial Maximum) led to hydraulic scouring of the seabed to a maximum depth of $204 \mathrm{~m}$ (Voris 2000, Bird et al. 2006).

As a result of such eustatic variations and its geographic setting, the Singapore Strait has developed into part of a vital international shipping link between the Indian Ocean and the South China Sea and beyond (Chua et al. 2000). A substantial proportion $(35 \%)$ of vessels that call at the international harbor of Singapore are ferries that connect with ports in the Riau Islands, including Bintan (Chou 2006). The latter has established itself as a hinterland of Singapore for tourism since the setup of the 23,000 ha Bintan Beach International Resort in the late 1990s, a joint project between the Indonesian and Singapore governments as well as private investors (Peachey et al. 1998, Wong 1998, Bunnell et al. 2006). With a set of diverse ecosystems fringing its northern coast (e.g., subtidal coral reef, intertidal shore, mangrove, and freshwater streams) (Chou et al. 1993), it was an optimal location for ecotourism. Unfortunately, development was mostly devoid of consideration for sustainable tourism (Chua et al. 2000). For instance, most of the natural beach vegetation (e.g., Scaevola and Padanus) was cleared, priming conditions for coastal erosion (Wong 2003).

As a step forward, several resort managers in Bintan were responsible for initiating the current assessment of the reefs. In August 2007, we conducted transect surveys to determine the current condition of the coral reef benthos and fish communities at locations similar to or adjacent to several sites examined in the 1993 study (i.e., between Tanjung Tondang and Pulau Sumpat. Results are compared with findings in the previous assessment.
MATERIALS AND METHODS

Five reef sites along the northern coast of Bintan Island were surveyed via scuba in $\mathrm{Au}-$ gust 2007: (1) Tanjung Tondang (01 $11^{\circ} 01^{\prime \prime}$ N, $\left.104^{\circ} 19^{\prime} 10^{\prime \prime} \mathrm{E}\right)$; (2) Pulau Rawa $\left(01^{\circ} 11^{\prime}\right.$ $\left.26^{\prime \prime} \mathrm{N}, 104^{\circ} 20^{\prime} 17^{\prime \prime} \mathrm{E}\right)$; (3) Pulau Maoi (01 ${ }^{\circ}$ $11^{\prime} 38^{\prime \prime} \mathrm{N}, 104^{\circ} 22^{\prime} 27^{\prime \prime} \mathrm{E}$ ); (4) Stingray Point $\left(01^{\circ} 10^{\prime} 55^{\prime \prime} \mathrm{N}, 104^{\circ} 27^{\prime} 52^{\prime \prime} \mathrm{E}\right)$; and (5) Pulau

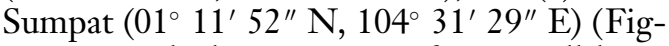
ure 1). With the exception of site 4, all locations were similar to those studied in 1993. At each site, five $25 \mathrm{~m}$ fiberglass transect tapes were randomly placed parallel to shore at a specific depth between $3.8 \mathrm{~m}$ and $5.0 \mathrm{~m}$ below chart datum. Horizontal underwater visibility ranged from $3 \mathrm{~m}$ to $6 \mathrm{~m}$.

The line intercept transect (LIT) method (English et al. 1997) was employed to survey the reef benthic community, which was characterized with five biotic and abiotic categories (i.e., live hard coral, dead hard coral, algae, other fauna [including soft corals, sponges, and zoanthids], and abiotic substrate [including rock, rubble, sand, and silt]). Along-transect swims were performed for $20 \mathrm{~m}$ of each of the five transects, and benthic forms underlying the tape were recorded. Live hard corals were identified to generic level.

For the fish community, the fish visual census (FVC) method (English et al. 1997) was used. At each site, before the benthic survey and $10 \mathrm{~min}$ after the fiberglass tapes were deployed, the surveyor swam slowly along the transect and identified and counted all fish species encountered within a belt $3 \mathrm{~m}$ to the left, right, and above the tape. Only the first, third, and fifth transects $(25 \mathrm{~m}$ each) were surveyed to minimize recounting.

Raw data were analyzed by calculating several parameters separately for the fish and benthic communities. They include species richness and size-class distribution of corals as well as percentage benthic cover or fish abundance. The Shannon-Wiener diversity index ( $\mathrm{S}-\mathrm{W}$ index) was also computed for fish and coral taxa. Because the number of transects per site was expected to be insufficient to satisfy assumptions of the $t$-test, the nonparametric two-sample Mann-Whitney 
$U$-test was used to examine temporal variations in abundances of various benthic biotic categories and coral richness. The same test was employed to compare diversity, richness, abundance, and dominance of fish species between 1993 and 2007. The Wilcoxon signed-rank test was performed to investigate dominance of coral genera at each site because raw data were not available for that taxonomic level. All statistical analyses were carried out in STATISTICA 6.0 (StatSoft, Inc., Tulsa, Oklahoma).

\section{RESULTS}

The reef environment at Pulau Maoi and Pulau Sumpat consisted of relatively extensive reef flats that are demarcated by distinct crests and short stretches of slope, leveling off at a vertical depth of $12-15 \mathrm{~m}$ to a sandy or sand-silt seafloor. In contrast, reefs at the other three sites were narrower, with relatively indistinct crests. The underlying substrate at all sites was observed to be noncarbonate. This was, however, less obvious at Pulau Maoi, where coral growth completely covered the seafloor with only small patches of noncarbonate substrate exposed.

Among the five sites, a total of 43 hardcoral genera was found, with a mean live coral cover of $53.4 \%$ ( \pm SE $13.7 \%$ ) along the surveyed transects (Table 1 ). The highest $S-W$ index was recorded in Pulau Rawa (2.95), and the mean for all sites was $2.51( \pm \mathrm{SE}$ 0.43) (Figure 2). Stingray Point registered the greatest hard coral cover of all sites, with mean $64.7 \%( \pm \mathrm{SE} 13.0 \%)$, and the lowest mean cover of $35.0 \%( \pm$ SE $16.5 \%)$ was recorded at Tanjung Tondang. The remaining three sites all had similar cover between $56.6 \%( \pm$ SE 5.4\% [Pulau Maoi]) and 58.5\% $( \pm \mathrm{SE} 4.8 \%$ [Pulau Sumpat; lowest S-W index of 1.99]). The number of hard coral genera recorded at each site ranged from 23 at Tanjung Tondang to 35 at Pulau Maoi. Foliose coral Turbinaria and massive coral Porites were the most common, both in occurrence and relative abundance at all sites except for Pulau Maoi, where tabulate Acropora dominated in occurrence but not percentage
TABLE 1

List of Hard Coral Genera Recorded in 1993 and 2007

\begin{tabular}{|c|c|c|}
\hline Coral Genera & 1993 & 2007 \\
\hline Acanthastrea & $X$ & $X$ \\
\hline Acropora & $X$ & $X$ \\
\hline Alveopora & $X$ & \\
\hline Astreopora & $X$ & $\mathrm{X}$ \\
\hline Caulastrea & $\mathrm{X}$ & $X$ \\
\hline Coeloseris & $X$ & $X$ \\
\hline \multicolumn{3}{|l|}{ Coscinaraea } \\
\hline \multicolumn{3}{|l|}{ Ctenactis } \\
\hline Cyphastrea & $X$ & $X$ \\
\hline Diploastrea & $X$ & $X$ \\
\hline Echinophyllia & $X$ & $X$ \\
\hline Echinopora & $X$ & $X$ \\
\hline Eupbyllia & $X$ & $\mathrm{X}$ \\
\hline Favia & $\mathrm{X}$ & $X$ \\
\hline Favites & $\mathrm{X}$ & $\mathrm{X}$ \\
\hline Fungia & $X$ & $X$ \\
\hline Galaxea & $X$ & $X$ \\
\hline Goniastrea & $X$ & $X$ \\
\hline Goniopora & $X$ & $X$ \\
\hline \multicolumn{3}{|l|}{ Heliofungia } \\
\hline Heliopora & $\mathrm{X}$ & $\mathrm{X}$ \\
\hline Herpolitha & $X$ & $X$ \\
\hline Hydnophora & $\mathrm{X}$ & $\mathrm{X}$ \\
\hline Leptastrea & $\mathrm{X}$ & $X$ \\
\hline Leptoria & $\mathrm{X}$ & \\
\hline Lithophyllon & $X$ & $X$ \\
\hline Lobophyllia & $X$ & $X$ \\
\hline Merulina & $X$ & $X$ \\
\hline Millepora & $X$ & \\
\hline Montastrea & $X$ & $\mathrm{X}$ \\
\hline Montipora & $\mathrm{X}$ & $\mathrm{X}$ \\
\hline Mycedium & $X$ & $X$ \\
\hline \multicolumn{3}{|l|}{ Oulastrea } \\
\hline Oxypora & $X$ & $\mathrm{X}$ \\
\hline Pachyseris & $\mathrm{X}$ & $\mathrm{X}$ \\
\hline Pavona & $\mathrm{X}$ & $X$ \\
\hline Pectinia & $X$ & $X$ \\
\hline Platygyra & $X$ & $X$ \\
\hline Plerogyra & $X$ & $\mathrm{X}$ \\
\hline Pocillopora & $X$ & $X$ \\
\hline Podabacia & $X$ & $\mathrm{X}$ \\
\hline Porites & $\mathrm{X}$ & $X$ \\
\hline Scapophyllia & $X$ & \\
\hline Scolymia & $\mathrm{X}$ & \\
\hline \multicolumn{3}{|l|}{ Stylocoeniella } \\
\hline Stylophora & $X$ & $\mathrm{X}$ \\
\hline Symphyllia & $X$ & $X$ \\
\hline Turbinaria & $\mathrm{X}$ & $\mathrm{X}$ \\
\hline
\end{tabular}

cover. Size-class distribution was generally similar between sites-colonies $10-25 \mathrm{~cm}$ were the most common at all five sites.

Sponges, soft corals, and other fauna were 


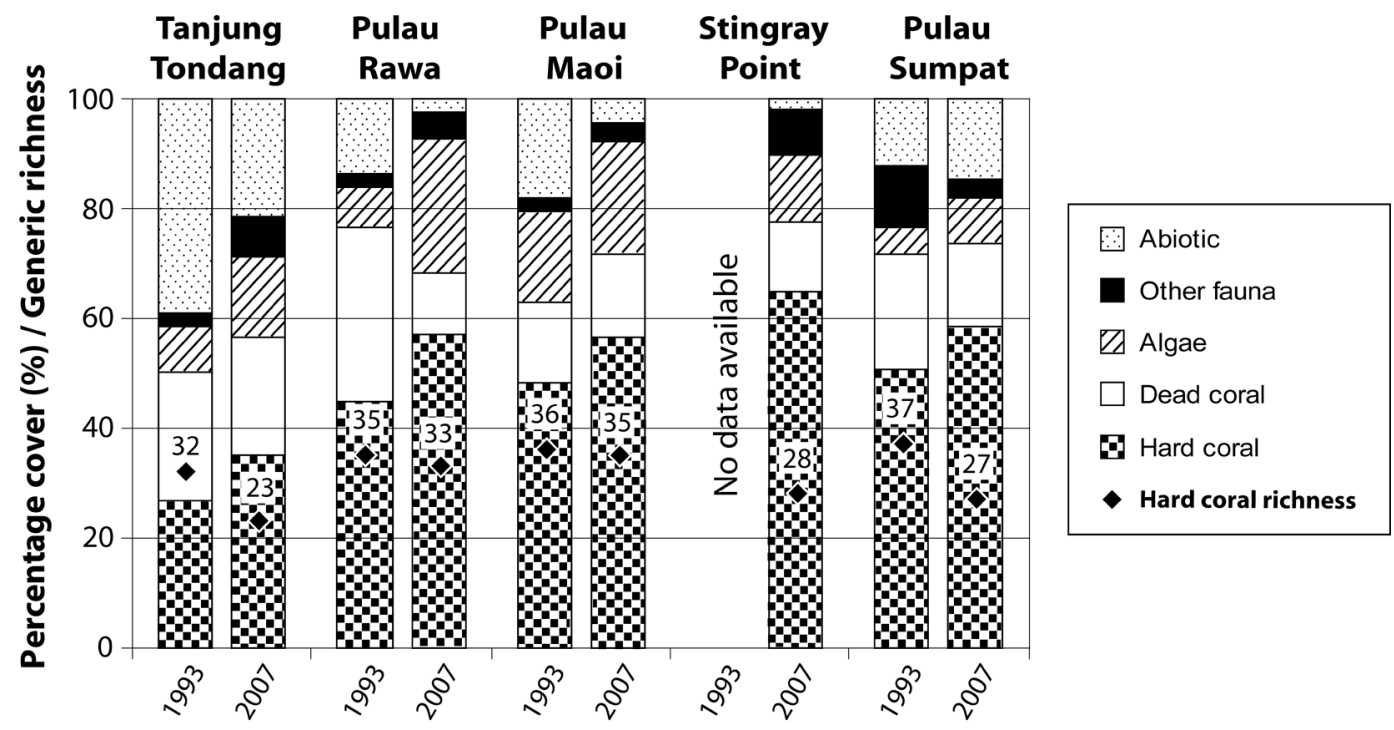

Figure 2. Mean percentage cover of five biotic and abiotic categories at the surveyed sites in 1993 and 2007, with generic richness of hard corals indicated.

generally not common, with highest abundances recorded in Stingray Point and Tanjung Tondang, $8.1 \%( \pm \mathrm{SE} 6.6 \%)$ and $7.6 \%$ $( \pm$ SE $6.0 \%)$, respectively. Algal cover varied from a low of $8.5 \%( \pm$ SE $7.4 \%)$ at Pulau Sumpat to a high of $24.6 \%( \pm$ SE $5.8 \%)$ at Pulau Rawa. Percentage dead coral ranged from mean $11.3 \% \quad( \pm \mathrm{SE} \quad 1.6 \%$ [Pulau Rawa]) to $15.3 \% \quad( \pm \mathrm{SE} \quad 14.5 \% \quad$ [Pulau Maoi]), except at Tanjung Tondang, which recorded an exceptionally high cover of $21.6 \%$ ( \pm SE 11.1\%). Minor components were coral rubble (all sites $\leq 5.8 \%$ ), silt, and sand (pooled mean of $0.17-4.4 \%$ ).

We recorded a total of 4,420 fish individuals from 63 species and 16 families (Table 2). The most abundant fish families ( $>40$ individuals per site) were the butterflyfishes, cardinalfishes, damselfishes, and fusiliers. Highly targeted fishes such as groupers and snappers were also observed, but only a few individuals were recorded (groupers: 1.6 individuals per site; snappers: 3.2 individuals per site). Tanjung Tondang registered the largest number of fish species (40 spp.) and abundance $(1,169$ individuals), but the most diverse reef was found at Stingray Point, with a Shannon-
Wiener index of 2.40 (Figure 3). This is a result of strong dominance of one particular species at all other sites. For instance, $51.8 \%$ of all individuals encountered at Pulau Maoi were Pomacentrus moluccensis. Conversely, the most dominant species at Stingray Point, $\mathrm{Am}$ bassis sp., accounted for less than one-fourth of all fish surveyed. In general, Ambassis sp. was the most common fish recorded $(30.3 \%$ of total abundance).

Variations in the reef biota have occurred since 1993. For all sites with valid comparisons (i.e., except Stingray Point), although mean hard coral abundance appears to have risen qualitatively, the change is only marginally significant at Pulau Sumpat $(U=0.00$, $\left.P=.053, n_{1993}=2, n_{2007}=5\right)$. Pooled across all sites, there was no significant difference in mean hard coral cover $(U=60.00, P=.149$, $\left.n_{1993}=8, n_{2007}=23\right)$. Mean abundance of algae, with coralline algae as the major component, increased at all sites but was only marginally significant at Pulau Rawa $(U=$ $\left.0.00, P=.053, n_{1993}=2, n_{2007}=5\right)$. Other notable changes are decreases in coverage of dead coral at Pulau Rawa $(U=0.00, P=$ $.053, n_{1993}=2, n_{2007}=5$ ) and other fauna at 
TABLE 2

List of Fish Species Recorded in 1993 and 2007

\begin{tabular}{|c|c|c|c|c|c|}
\hline Fish Species & 1993 & 2007 & Fish Species & 1993 & 2007 \\
\hline Abudefduf bengalensis (Bloch) & $\mathrm{X}$ & $\mathrm{X}$ & Halichoeres nigrescens (Bloch \& Schneider) & $\mathrm{X}$ & $\mathrm{X}$ \\
\hline Abudefduf sexfasciatus (Lacepède) & $\mathrm{X}$ & $\mathrm{X}$ & Halichoeres scapularis (Bennett) & $X$ & $X$ \\
\hline Abudefduf vaigiensis (Quoy \& Gaimard) & $X$ & $\mathrm{X}$ & Halichoeres sp. & $\mathrm{X}$ & \\
\hline Acantburus triostegus (Linnaeus) & & $\mathrm{X}$ & Halichoeres vrolikii (Bleeker) & $\mathrm{X}$ & X \\
\hline Aeoliscus strigatus (Günther) & $X$ & & Hemiglyphidodon plagiometopon (Bleeker) & $\mathrm{X}$ & \\
\hline Ambassid sp. & & $\mathrm{X}$ & Hemigymnus melapterus (Bloch) & $\mathrm{X}$ & \\
\hline Amblyglyphidodon aureus (Cuvier) & $\mathrm{X}$ & $\mathrm{X}$ & Kyphosus sp. & $\mathrm{X}$ & \\
\hline Amblyglyphidodon curacao (Bloch) & $\mathrm{X}$ & $\mathrm{X}$ & Labroides dimidiatus (Valenciennes) & $\mathrm{X}$ & \\
\hline Amphiprion akindynos Allen & & $\mathrm{X}$ & Lutjanus argentimaculatus (Forsskål) & $\mathrm{X}$ & \\
\hline Amphiprion clarkii (Bennett) & $\mathrm{X}$ & & Lutjanus carponotatus (Richardson) & $\mathrm{X}$ & $\mathrm{X}$ \\
\hline Amphiprion frenatus Brevoort & $X$ & & Lutjanus monostigma (Cuvier) & $\mathrm{X}$ & \\
\hline Amphiprion ocellaris Cuvier & $\mathrm{X}$ & $\mathrm{X}$ & Lutjanus russellii (Bleeker) & & $\mathrm{X}$ \\
\hline Amphiprion perideraion Bleeker & $X$ & $\mathrm{X}$ & Lutjanus sp. & $\mathrm{X}$ & \\
\hline Anampses meleagrides Valenciennes & & $\mathrm{X}$ & Monacanthus chinensis (Osbeck) & $X$ & X \\
\hline Apogon compressus (Smith \& Radcliffe) & $\mathrm{X}$ & $\mathrm{X}$ & Neoglyphidodon melas (Cuvier) & $\mathrm{X}$ & $\mathrm{X}$ \\
\hline Apogon maculatus (Poey) & & $\mathrm{X}$ & Neoglyphidodon nigroris (Cuvier) & $\mathrm{X}$ & \\
\hline Apogon sealei (Fowler) & $\mathrm{X}$ & & Neopomacentrus azysron (Bleeker) & $\mathrm{X}$ & \\
\hline Apogon sp. & $\mathrm{X}$ & $\mathrm{X}$ & Neopomacentrus filamentosus (Macleay) & $\mathrm{X}$ & \\
\hline Archamia fucata (Cantor) & $\mathrm{X}$ & & Paramonacanthus japonicus (Tilesius) & & $\mathrm{X}$ \\
\hline Caesio teres Seale & & $\mathrm{X}$ & Pempheris sp. & $\mathrm{X}$ & $\mathrm{X}$ \\
\hline Caesio cuning (Bloch) & $X$ & $\mathrm{X}$ & Pentapodus sp. & $\mathrm{X}$ & \\
\hline Cephalopholis boenak (Bloch) & $\mathrm{X}$ & $\mathrm{X}$ & Platax pinnatus (Linnaeus) & $\mathrm{X}$ & \\
\hline Cephalopholis formosa (Shaw) & $\mathrm{X}$ & $\mathrm{X}$ & Plectorbinchus chaetodonoides Lacepède & $\mathrm{X}$ & $\mathrm{X}$ \\
\hline Chaetodon adiergastos Seale & $X$ & & Plectorbinchus pictus (Tortonese) & $\mathrm{X}$ & \\
\hline Chaetodon octofasciatus Bloch & $\mathrm{X}$ & $\mathrm{X}$ & Pomacanthus annularis (Bloch) & $\mathrm{X}$ & $X$ \\
\hline Chaetodontoplus mesoleucus (Bloch) & $\mathrm{X}$ & $\mathrm{X}$ & Pomacanthus sexstriatus (Cuvier) & $X$ & \\
\hline Cheilinus fasciatus (Bloch) & & $\mathrm{X}$ & Pomacentrus albimaculus Allen & $\mathrm{X}$ & $\mathrm{X}$ \\
\hline Cheilinus trilobatus Lacepède & $\mathrm{X}$ & $\mathrm{X}$ & Pomacentrus alexanderae Evermann \& & $\mathrm{X}$ & \\
\hline Cheilinus undulatus Rüppell & $\mathrm{X}$ & & Seale & & \\
\hline Cheilodipterus quinquelineatus Cuvier & $\mathrm{X}$ & $\mathrm{X}$ & Pomacentrus brachialis Cuvier & $\mathrm{X}$ & \\
\hline Cheilodipterus intermedius Gon & & $\mathrm{X}$ & Pomacentrus chrysurus Cuvier & $X$ & $\mathrm{X}$ \\
\hline Cheilodipterus macrodon (Lacepède) & $X$ & $\mathrm{X}$ & Pomacentrus littoralis Cuvier & $\mathrm{X}$ & $\mathrm{X}$ \\
\hline Chelmon rostratus (Linnaeus) & $\mathrm{X}$ & $\mathrm{X}$ & Pomacentrus moluccensis Bleeker & $\mathrm{X}$ & $\mathrm{X}$ \\
\hline Choerodon anchorago (Bloch) & $\mathrm{X}$ & $\mathrm{X}$ & Pomacentrus sp. & $\mathrm{X}$ & \\
\hline Choerodon schoenleinii (Valenciennes) & $\mathrm{X}$ & $\mathrm{X}$ & Psammoperca waigiensis (Cuvier) & $\mathrm{X}$ & \\
\hline Chromis amboinensis (Bleeker) & & $\mathrm{X}$ & Salarias fasciatus (Bloch) & $\mathrm{X}$ & \\
\hline Chromis margaritifer Fowler & & $\mathrm{X}$ & Sargocentron rubrum (Forsskål) & $\mathrm{X}$ & $\mathrm{X}$ \\
\hline Cbrysiptera flavipinnis (Allen \& Robertson) & & $\mathrm{X}$ & Scarus ghobban Forsskål & $\mathrm{X}$ & $\mathrm{X}$ \\
\hline Dascyllus trimaculatus (Rüppell) & $\mathrm{X}$ & & Scarus sp. & $\mathrm{X}$ & \\
\hline Diademichthys lineatus (Sauvage) & & $\mathrm{X}$ & Scolopsis affinis Peters & $\mathrm{X}$ & \\
\hline Diploprion bifasciatum Cuvier & & $\mathrm{X}$ & Scolopsis ciliata (Lacepède) & $\mathrm{X}$ & $\mathrm{X}$ \\
\hline Diproctacanthus xanthurus (Bleeker) & $\mathrm{X}$ & & Scolopsis trilineata Kner & $X$ & $\mathrm{X}$ \\
\hline Dischistodus chrysopoecilus (Schlegel \& & $\mathrm{X}$ & $\mathrm{X}$ & Scolopsis vosmeri (Bloch) & $X$ & \\
\hline Müller) & & & Scomberoides commersonnianus Lacepède & $\mathrm{X}$ & \\
\hline Dischistodus perspicillatus (Cuvier) & $\mathrm{X}$ & & Selaroides leptolepis (Cuvier) & $\mathrm{X}$ & \\
\hline Dischistodus prosopotaenia (Bleeker) & $\mathrm{X}$ & $\mathrm{X}$ & Siganus guttatus (Bloch) & $\mathrm{X}$ & $\mathrm{X}$ \\
\hline Elagatis bipinnulata (Quoy \& Gaimard) & $\mathrm{X}$ & & Siganus lineatus (Valenciennes) & & $\mathrm{X}$ \\
\hline $\begin{array}{l}\text { Epinephelus malabaricus (Bloch \& } \\
\text { Schneider) }\end{array}$ & $\mathrm{X}$ & $\mathrm{X}$ & $\begin{array}{l}\text { Siganus sp. } \\
\text { Siganus viroatus (Valenciennes) }\end{array}$ & $\mathrm{X}$ & $X$ \\
\hline Epinephelus howlandi (Günther) & $X$ & & Synodus variegatus (Lacepède) & & $\mathrm{X}$ \\
\hline Gymnothorax sp. & $\mathrm{X}$ & & Sphyraena jello Cuvier & & $\mathrm{X}$ \\
\hline Halichoeres chloropterus (Bloch) & $\mathrm{X}$ & & Taeniura sp. & $\mathrm{X}$ & $\mathrm{X}$ \\
\hline Halichoeres margaritaceus (Valenciennes) & $\mathrm{X}$ & & Thalassoma lunare (Linnaeus) & $\mathrm{X}$ & \\
\hline Halichoeres melanochir Fowler \& Bean & $\mathrm{X}$ & $\mathrm{X}$ & Thalassoma sp. & $\mathrm{X}$ & \\
\hline Halichoeres melanurus (Bleeker) & $\mathrm{X}$ & & Upeneus tragula Richardson & $\mathrm{X}$ & $\mathrm{X}$ \\
\hline
\end{tabular}




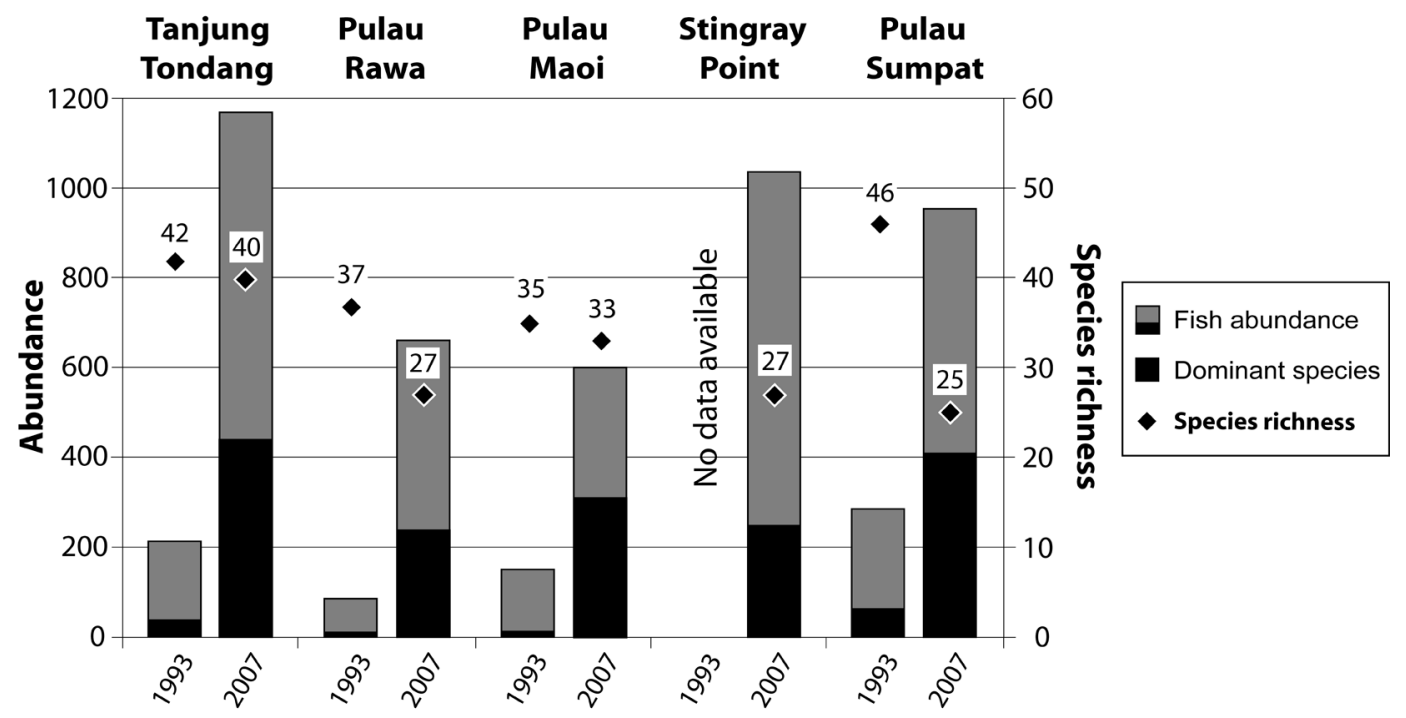

FIgURE 3. Total and dominant fish counts at the surveyed sites in 1993 and 2007. Species richness at each site is indicated.

Pulau Sumpat $\left(U=0.00, P=.051, n_{1993}=2\right.$, $n_{2007}=5$ ).

Variations in the abundance of particular genera of hard corals have also occurred. Tanjung Tondang and Pulau Sumpat shifted from Porites-dominated communities to being Turbinaria-dominated, with the most common genus an order of magnitude more prevalent in 2007 than in $1993(W=15.0, P=$ .043). In Pulau Rawa and Pulau Maoi, the shifts were from Lobophyllia and Pachyseris, respectively, to Porites as the dominant genus (only Pulau Maoi significant: $W=15.0, P=$ .043). These variations were accompanied by a general decrease in coral richness from 35.0 ( \pm SE 2.2) genera per site in 1993 to 29.5 $( \pm$ SE 4.8) genera per site in 2007 ; this change was marginally significant $(U=2.50$, $P=.065, n_{1993}=4, n_{2007}=5$ ).

Diversity of fish has decreased significantly since 1993. Averaged among sites, the mean Shannon-Wiener diversity index then was $3.05( \pm$ SE 0.15$)$ but dropped to $2.14( \pm$ SE $0.20)$ in $2007\left(U=0.00, P=0.014, n_{1993}=\right.$ $\left.4, n_{2007}=5\right)$, despite sizeable increases in total fish counts $\left(U=0.00, P=.014, n_{1993}=4\right.$, $n_{2007}=5$ ) (Figure 3). An almost fivefold increase in mean abundance was recorded (year
1993: mean $183 \pm$ SE 86; year 2007: mean $844 \pm$ SE 244). The augmented fish numbers were a result of shifts to communities dominated by fewer species. Mean species richness was 40.0 ( \pm SE 5.0) in 1993 but decreased significantly to $30.4( \pm$ SE 6.2$)$ in $2007(U=$ $\left.2.00, P=.049, n_{1993}=4, n_{2007}=5\right)$, accompanied by expansions in population numbers of the most common species $(U=0.00, P=$ .014, $n_{1993}=4, n_{2007}=5$ ).

\section{DISCUSSION}

During the 14 yr that transpired between the 1993 assessment and the 2007 survey, most of Pulau Bintan's northern coastline was taken over by resort development (Peachey et al. 1998, Wong 1998, Bunnell et al. 2006). Results show that hard coral cover at each of the sites remains high and even increased marginally at one site. Generic richness was also high - a total of 43 genera were recorded during the surveys, and an additional seven genera not captured within transects were observed at the sites. Of these, 48 are scleractinian reef corals, representing over $60 \%$ of the total generic richness within the IndoPacific (Cairns 1999). Similar trends were 
seen for fish communities, with expanded abundances at all sites. However, averaged across all sites, taxonomic richness has fallen since 1993, with fewer taxa dominating the reef. For instance, the massive coral Porites and the foliose coral Turbinaria were present in high abundances at all reefs surveyed. Recorded shifts in coral and fish assemblages suggest a certain level of influence by coastal development.

Pulau Sumpat appears to be the most impacted, with declines in nearly one-third of coral genera and half of fish species. Previously, this site was found to be low in coral abundance and did not harbor Acropora due to high outflow of freshwater (Low et al. 1995). In our study, the situation is similar for Acropora ( $<1 \%$ mean cover), and although a high cover of almost $60 \%$ was recorded in 2007 , compared with $50.6 \%$ in 1993 , coral genera richness fell during these $14 \mathrm{yr}$. This was accompanied by a shift of generic dominance from Porites to Turbinaria. Such a change also occurred in Tanjung Tondang. Porites has been shown to be relatively tolerant of salinity reductions (Moberg et al. 1997), which is the likely cause of its high prevalence before resort development in $\mathrm{Pu}-$ lau Sumpat. However, these massive colonies with small calices are relatively incapable of withstanding sedimentation (Stafford-Smith and Ormond 1992, Philipp and Fabricius 2003, but see Stafford-Smith 1993), and shifts to funnel-shape morphologies may occur in sedimented locations (Riegl et al. 1996). It has been shown that Turbinaria spp., which exemplify such inclined funnel shapes, have several other traits that enhance their sediment-rejection capabilities, including large widely spaced corallites, effective ciliary transport, and minimal coenosteal projections that may otherwise obstruct sediment removal via passive water movement across the colony surface (Stafford-Smith and Ormond 1992). Indeed, experiments have shown that Turbinaria mesenterina, the dominant species encountered in Pulau Sumpat and Tanjung Tondang, can survive well in those areas (Sofonia and Anthony 2008). The dynamics of the recorded temporal variations in coral composition may therefore be explained by freshwater influences and coastal development.

Phase shifts from coral- to algaldominated reefs have been studied extensively in recent years (Done et al. 1991, Done 1992, Knowlton 1992, Hughes 1994, McClanahan et al. 1999, McCook 1999, Bellwood et al. 2004, 2006, McManus and Polsenberg 2004, Baird et al. 2005, Ledlie et al. 2007). Less well documented are communities that have tended toward the dominance of other cnidarians such as corallimorphs and anemones (Chen and Dai 2004, Kuguru et al. 2004, Tkachenko et al. 2007, Work et al. 2008). Here, we report the increase of algae abundance at the expense of hard coral cover. Fortunately, the main component contributing to this change was coralline algae, an important reef calcifier and consolidator (Adey 1998, Chisholm 2003, Kuffner et al. 2008). More dramatically, a shift in hard coral dominance has occurred, from the massive Porites to foliose Turbinaria, and is likely to be associated with the local sediment regime.

Compared with other localities in Southeast Asia, sedimentation rates in sheltered reefs here are relatively high, as recorded in neighboring reefs of Singapore (e.g., Pulau Semakau: 4.36-83.6 $\mathrm{mg} \mathrm{cm}{ }^{-2}$ day $^{-1}$ [Hilton and Chou 1999, Chou et al. 2004]). It is not surprising that we found underwater visibility to be low at Bintan Island's reefs. It averaged from $6 \mathrm{~m}$ at Stingray Point to $3 \mathrm{~m}$ at Pulau Rawa and Tanjung Todang (pers. obs.). Compared with coral reefs of Pulau Tioman and Pulau Redang along the eastern coast of Peninsular Malaysia, where average visibility during the nonmonsoon diving season from March to November ranges from $6 \mathrm{~m}$ to $15 \mathrm{~m}$, the visibility observed at the surveyed sites can only be considered average or poor. On the other hand, the northern coast of Bintan Island faces the South China Sea and is fully exposed to the northeast monsoon between December and February each year. It is sheltered from the June to August southwest monsoon. Tidal currents in the Singapore Strait flow stronger westward than eastward (Chan et al. 2006), isolating Bintan's 
reefs from sedimentation impacts from Singapore, Peninsular Malaysia, and the other Riau Islands west of Bintan. Coastal development and freshwater runoff from within the island are likely to dominate the influences on its reef environment. Other causes of declining water quality in Bintan include haze from the Indonesian wildfires, which affects coral physiology (Risk et al. 2003), and the high hydrocarbon concentration recorded (10.05 ppm) (Nontji 2004). The latter has been hypothesized to originate from tankers and other vessels that ply the Singapore Strait.

Despite the lack of clear and good-quality water, which may have contributed to the declines shown in this study, the reefs still show a fair degree of diversity and consolidation, as indicated by the high proportion of coralline algae at most sites. This, in turn, supports a host of other reef-associated flora and fauna. To halt possible development-related shifts in these communities, a comprehensive integrated coastal management plan needs to be in place as soon as possible (Bellwood et al. 2004; see also Dodge et al. 2008).

We are aware of the development of a national framework for community-based management system at some areas in the Riau archipelago (Nontji 2000). Although it was reported by IUCN that some level of success in the plan has been achieved, the proxy has been the awareness of reef conservation needs among the local communities (Hidayati 2003). Fishing for livelihood still occurs at many reefs along Bintan's north coast. Thus it is important to manage the habitats effectively to ensure that resources for local fisheries can be sustained in the long term (White 1986, Murray et al. 1999, Lundquist and Granek 2005, Wilkinson et al. 2006, Mumby and Steneck 2008, Ruckelshaus et al. 2008). We therefore urge the establishment of Marine Protected Areas that include the coasts of Pulau Bintan in the hope that legislation will curb further declines in reef quality.

\section{ACKNOWLEDGMENTS}

This study was carried out in partnership and with logistical support by the Bintan Resorts
Management, Angsana Resort and Spa Bintan, Club Med Ria Bintan, Bintan Lagoon Resort, and Mayang Sari Beach Resort. We are grateful for assistance from members of the Marine Biology Laboratory at the National University of Singapore. We also thank two anonymous reviewers who provided constructive comments on the manuscript.

\section{Literature Cited}

Adey, W. H. 1998. Coral reefs: Algal structured and mediated ecosystems in shallow, turbulent, alkaline waters. J. Phycol. 34:393-406.

Allen, G. R. 2000. Indo-Pacific coral-reef fishes as indicators of conservation hotspots. Proc. 9th Int. Coral Reef Symp. 2:921-926.

. 2001. Reef fishes of the Togean and Banggai islands, Sulawesi, Indonesia. Pages 44-53 in G. R. Allen and S. A. McKenna, eds. A Marine Rapid Assessment of the Togean and Banggai islands, Sulawesi, Indonesia. Conservation International, Washington, D.C.

Allen, G. R., and T. B. Werner. 2002. Coral reef fish assessment in the 'coral triangle' of southeastern Asia. Environ. Biol. Fishes 65:209-214.

Baird, A. H., S. J. Campbell, A. W. Anggoro, R. L. Ardiwijaya, N. Fadli, Y. Herdiana, T. Kartawijaya, D. Mahyiddin, A. Mukminin, S. T. Pardede, M. S. Pratchett, E. Rudi, and A. M. Siregar. 2005. Acehnese reefs in the wake of the Asian tsunami. Curr. Biol. 15:1926-1930.

Bellwood, D. R., T. P. Hughes, C. Folke, and M. Nystrom. 2004. Confronting the coral reef crisis. Nature (Lond.) 429:827-833.

Bellwood, D. R., T. P. Hughes, and A. S. Hoey. 2006. Sleeping functional group drives coral-reef recovery. Curr. Biol. 16:2434-2439.

Bird, M. I., W. C. Pang, and K. Lambeck. 2006. The age and origin of the Straits of Singapore. Palaeogeogr. Palaeoclimatol. Palaeoecol. 241:531-538.

Briggs, J. C. 1999. Coincident biogeographic 
patterns: Indo-West Pacific Ocean. Evolution 53:326-335.

2000. Centrifugal speciation and centres of origin. J. Biogeogr. 27:11831188.

Bruno, J. F., and E. R. Selig. 2007. Regional decline of coral cover in the Indo-Pacific: Timing, extent, and subregional comparisons. PLoS ONE 2:e711.

Bunnell, T., H. Muzaini, and J. D. Sidaway. 2006. Global city frontiers: Singapore's hinterland and the contested sociopolitical geographies of Bintan, Indonesia. Int. J. Urban Reg. Res. 30:3-22.

Burke, L., E. Selig, and M. Spalding. 2002. Reefs at risk in Southeast Asia. World Resources Institute, Washington, D.C.

Cairns, S. D. 1999. Species richness of recent Scleractinia. Atoll Res. Bull. 459:1-46.

Carpenter, K. E., and V. G. Springer. 2005. The center of the center of marine shore fish biodiversity: the Philippine Islands. Environ. Biol. Fishes 72:467-480.

Casey, S. P., H. J. Hall, H. F. Stanley, and A. C. J. Vincent. 2004. The origin and evolution of seahorses (genus Hippocampus): A phylogenetic study using the cytochrome $b$ gene of mitochondrial DNA. Mol. Phylogenet. Evol. 30:261-272.

Chan, E. S., P. Tkalich, K. Y. H. Gin, and J. P. Obbard. 2006. The physical oceanography of Singapore coastal waters and its implications for oil spills. Pages 393-412 in E. Wolanski, ed. The environment in Asia Pacific harbours. Springer, The Netherlands.

Chen, C. A., and C. F. Dai. 2004. Local phase shift from Acropora-dominant to Condylactis-dominant community in the Tiao-Shi Reef, Kenting National Park, southern Taiwan. Coral Reefs 23:508.

Chisholm, J. R. M. 2003. Primary productivity of reef-building crustose coralline algae. Limnol. Oceanogr. 48:1376-1387.

Chou, L. M. 2006. Marine habitats in one of the world's busiest harbours. Pages 377391 in E. Wolanski, ed. The environment in Asia Pacific harbours. Springer, The Netherlands.

Chou, L. M., D. H. Murphy, and P. K. L. Ng. 1993. An assessment of the biological communities on the northern coast of Pulau Bintan, Indonesia. Environmental impact assessment report submitted to Bintan Resort Management, Singapore. (Available from the authors.)

Chou, L. M., J. Y. Yu, and T. L. Loh. 2004. Impacts of sedimentation on soft-bottom benthic communities in the southern islands of Singapore. Hydrobiologia 515:91-106.

Chua, T. S., I. R. L. Gorre, S. A. Ross, S. R. Bernad, B. Gervacio, and M. C. Ebarvia. 2000. The Malacca Straits. Mar. Pollut. Bull. 41:160-178.

Dodge, R. E., C. Birkeland, M. Hatziolos, J. Kleypas, S. R. Palumbi, O. HoeghGuldberg, R. van Woesik, J. C. Ogden, R. B. Aronson, B. D. Causey, and F. Staub. 2008. A call to action for coral reefs. Science (Washington, D.C.) 322:189-190.

Done, T. J. 1992. Phase shifts in coral reef communities and their ecological significance. Hydrobiologia 247:121-132.

Done, T. J., P. K. Dayton, A. E. Dayton, and R. Steger. 1991. Regional and local variability in recovery of shallow coral communities: Moorea, French Polynesia and central Great Barrier Reef. Coral Reefs 9:183-192.

Ekman, S. 1953. Zoogeography of the sea. Sidgwick and Jackson, London.

English, S., C. Wilkinson, and V. Baker. 1997. Survey manual for tropical marine resources. 2nd ed. ASEAN-Australia marine science project: Living coastal resources. Australian Institute of Marine Science, Townsville.

Ge, X. J., and M. Sun. 2001. Population genetic structure of Ceriops tagal (Rhizophoraceae) in Thailand and China. Wetlands Ecol. Manage. 9:203-209.

Hidayati, D. 2003. Coral reef rehabilitation and management program in Indonesia. Pages 303-319 in Proceedings, 3rd International Surfing Reef Symposium, Raglan, New Zealand.

Hilton, M. J., and L. M. Chou. 1999. Sediment facies of a low-energy, meso-tidal fringing reef, Singapore. Singapore J. Trop. Geogr. 20:111-130.

Hoegh-Guldberg, O., P. J. Mumby, A. J. 
Hooten, R. S. Steneck, P. Greenfield, E. Gomez, C. D. Harvell, P. F. Sale, A. J. Edwards, K. Caldeira, N. Knowlton, C. M. Eakin, R. Iglesias-Prieto, N. Muthiga, R. H. Bradbury, A. Dubi, and M. E. Hatziolos. 2007. Coral reefs under rapid climate change and ocean acidification. Science (Washington, D.C.) 318:17371742.

Hoeksema, B. W. 2007. Delineation of the Indo-Malayan centre of maximum marine biodiversity: The Coral Triangle. Pages 117-178 in W. Renema, ed. Biogeography, time, and place: Distributions, barriers, and islands. Springer, The Netherlands.

Hughes, T. P. 1994. Catastrophes, phase shifts, and large-scale degradation of a Caribbean coral reef. Science (Washington, D.C.) 265:1547-1551.

Hughes, T. P., A. H. Baird, D. R. Bellwood, M. Card, S. R. Connolly, C. Folke, R. Grosberg, O. Hoegh-Guldberg, J. B. C. Jackson, J. Kleypas, J. M. Lough, P. Marshall, M. Nystrom, S. R. Palumbi, J. M. Pandolfi, B. Rosen, and J. Roughgarden. 2003. Climate change, human impacts, and the resilience of coral reefs. Science (Washington, D.C.) 301:929-933.

Humphries, U. W., and D. J. Webb. 2008. On the Indonesian Throughflow in the OCCAM 1/4 degree ocean model. Ocean Sci. 4:183-198.

Knowlton, N. 1992. Thresholds and multiple stable states in coral reef community dynamics. Am. Zool. 32:674-682.

Kuffner, I. B., A. J. Anderson, P. L. Jokiel, K. S. Rodgers, and F. T. Mackenzie. 2008. Decreased abundance of crustose coralline algae due to ocean acidification. Nat. Geosci. 1:114-117.

Kuguru, B. L., Y. D. Mgaya, M. C. Öhman, and G. M. Wagner. 2004. The reef environment and competitive success in the Corallimorpharia. Mar. Biol. (Berl.) 145: 875-884.

Leaw, C. P., P. T. Lim, A. Ahmad, and G. Usup. 2001. Genetic diversity of Ostreopsis ovata (Dinophyceae) from Malaysia. Mar. Biotechnol. 3:246-255.

Ledlie, M. H., N. A. J. Graham, J. C. Bythell,
S. K. Wilson, S. Jennings, N. V. C. Polunin, and J. Hardcastle. 2007. Phase shifts and the role of herbivory in the resilience of coral reefs. Coral Reefs 26:641-653.

Lourie, S. A., and A. C. J. Vincent. 2004. A marine fish follows Wallace's Line: The phylogeography of the three-spot seahorse (Hippocampus trimaculatus, Syngnathidae, Teleostei) in Southeast Asia. J. Biogeogr. 31:1975-1985.

Low, J. K. Y., P. K. L. Ng, and L. M. Chou. 1995. Using obligate symbiont populations as indicators of near-shore coral reef health. Pages 246-250 in D. Watson, K. S. Ong, and G. Vigers, eds. ASEAN criteria and monitoring: Advances in marine environmental management and human health protection, Proceedings of the ASEANCanada Midterm Technical Review Conference on Marine Science (24-28 October 1994). EVS Environmental Consultants, Vancouver, and National Science and Technology Board, Singapore.

Lundquist, C. J., and E. F. Granek. 2005. Strategies for successful marine conservation: Integrating socioeconomic, political, and scientific factors. Conserv. Biol. 19:1771-1778.

McClanahan, T. R., R. B. Aronson, W. F. Precht, and N. A. Muthiga. 1999. Fleshy algae dominate remote coral reefs of Belize. Coral Reefs 18:61-62.

McCook, L. J. 1999. Macroalgae, nutrients and phase shifts on coral reefs: Scientific issues and management consequences for the Great Barrier Reef. Coral Reefs 18:357-367.

McManus, J. W., and J. F. Polsenberg. 2004. Coral-algal phase shifts on coral reefs: Ecological and environmental aspects. Prog. Oceanogr. 60:263-279.

Moberg, F., M. Nyström, N. Kautsky, M. Tedengren, and P. Jarayabhand. 1997. Effects of reduced salinity on the rates of photosynthesis and respiration in the hermatypic corals Porites lutea and Pocillopora damicornis. Mar. Ecol. Prog. Ser. 157:5359.

Morton, B., and G. Blackmore. 2001. South China Sea. Mar. Pollut. Bull. 42:12361263. 
Mumby, P. J., and R. S. Steneck. 2008. Coral reef management and conservation in light of rapidly evolving ecological paradigms. Trends Ecol. Evol. 23:555-563.

Murray, S. N., R. F. Ambrose, J. A. Bohnsack, L. W. Botsford, M. H. Carr, G. E. Davis, P. K. Dayton, D. Gotshall, D. R. Gunderson, M. A. Hixon, J. Lubchenco, M. Mangel, A. MacCall, D. A. McArdle, J. C. Ogden, J. Roughgarden, R. M. Starr, M. J. Tegner, and M. M. Yoklavich. 1999. No-take reserve networks: Sustaining fishery populations and marine ecosystems. Fisheries (Bethesda) 24:11-25.

Nontji, A. 2000. Coral reefs of Indonesia: Past, present and future. Proc. 9th Int. Coral Reef Symp. 1:17-27.

2004. Managing the marine environment of the Straits of Malacca. Paper presented in the Conference on the Straits of Malacca (11-13 October 2004), Kuala Lumpur. (Available from the authors.)

Pang, W. C., and P. Tkalich. 2003. Modeling tidal and monsoon driven currents in the Singapore Strait. Singapore Marit. Port J. 2003:151-162.

Peachey, K., M. Perry, and C. Grundy-Warr. 1998. The Riau Islands and economic cooperation in the Singapore Indonesian Border Zone. International Boundaries Research Unit, University of Durham, Durham, United Kingdom.

Philipp, E., and K. E. Fabricius. 2003. Photophysiological stress on scleractinian corals in response to short-term sedimentation. J. Exp. Mar. Biol. Ecol. 287:57-78.

Reid, D. G., K. Lal, J. Mackenzie-Dodds, F. Kaligis, D. T. J. Littlewood, and S. T. Williams. 2006. Comparative phylogeography and species boundaries in Echinolittorina snails in the central Indo-West Pacific. J. Biogeogr. 33:990-1006.

Riegl, B., C. Heine, and G. M. Branch. 1996. Function of funnel-shaped coral growth in a high-sedimentation environment. Mar. Ecol. Prog. Ser. 145:87-93.

Risk, M. J., O. A. Sherwood, J. M. Heikoop, and G. Llewellyn. 2003. Smoke signals from corals: Isotopic signature of the 1997 Indonesian 'haze' event. Mar. Geol. 202:71-78.
Ruckelshaus, M., T. Klinger, N. Knowlton, and D. P. DeMaster. 2008. Marine ecosystem-based management in practice: Scientific and governance challenges. BioScience 58:53-63.

Singleton, J., R. Sulaiman, and The Nature Conservancy. 2002. Environmental assessment study-Komodo National Park, Indonesia. The Nature Conservancy Southeast Asia Center for Marine Protected Areas, Bali, Indonesia. www .komodonationalpark.org/Download_our reports.htm

Sofonia, J. J., and K. R. N. Anthony. 2008. High-sediment tolerance in the reef coral Turbinaria mesenterina from the inner Great Barrier Reef lagoon (Australia). Estuarine Coast. Shelf Sci. 78:748-752.

Spalding, M. D., C. Ravilious, and E. P. Green. 2001. World atlas of coral reefs. University of California Press, Berkeley.

Stafford-Smith, M. G. 1993. Sedimentrejection efficiency of 22 species of Australian scleractinian corals. Mar. Biol. (Berl.) 115:229-243.

Stafford-Smith, M. G., and R. F. G. Ormond. 1992. Sediment-rejection mechanisms of 42 species of Australian scleractinian corals. Aust. J. Mar. Freshwater Res. 43:683705 .

Tkachenko, K. S., B. J. Wu, L. S. Fang, and T. Y. Fan. 2007. Dynamics of a coral reef community after mass mortality of branching Acropora corals and an outbreak of anemones. Mar. Biol. (Berl.) 151:185194.

Tun, K. P. P., L. M. Chou, A. Cabanban, V. S. Tuan, PhilReefs, T. Yeemin, Suharsono, K. Sour, and D. Lane. 2004. Status of coral reefs, coral reef monitoring and management in Southeast Asia, 2004. Pages 235-276 in C. Wilkinson, ed. Status of coral reefs of the world: 2004. Australian Institute of Marine Science, Townsville.

Veron, J. E. N. 2000. Corals of the world. Australian Institute of Marine Science, Townsville.

Voris, H. K. 2000. Maps of Pleistocene sea levels in Southeast Asia: Shorelines, river systems and time durations. J. Biogeogr 27:1153-1167. 
White, A. T. 1986. Marine reserves: How effective as management strategies for Philippine, Indonesian and Malaysian coral reef environments. Ocean Manage. 10:137-159.

White, A. T., and H. P. Vogt. 2000. Philippine coral reefs under threat: Lessons learned after 25 years of community-based reef conservation. Mar. Pollut. Bull. 40:537-550.

Wilkinson, C., A. Caillaud, L. DeVantier, and R. South. 2006. Strategies to reverse the decline in valuable and diverse coral reefs, mangroves and fisheries: The bottom of the J-Curve in Southeast Asia? Ocean Coastal Manage. 49:764-778.

Wong, P. P. 1998. Coastal tourism development in Southeast Asia: Relevance and les- sons for coastal zone management. Ocean Coastal Manage. 38:89-109.

- 2003. Where have all the beaches gone? Coastal erosion in the tropics. Singapore J. Trop. Geogr. 24:111-132.

Work, T. M., G. S. Aeby, and J. E. Maragos. 2008. Phase shift from a coral to a corallimorph-dominated reef associated with a shipwreck on Palmyra Atoll. PLoS ONE 3:e2989.

Worm, B., E. B. Barbier, N. Beaumont, J. E. Duffy, C. Folke, B. S. Halpern, J. B. C. Jackson, H. K. Lotze, F. Micheli, S. R. Palumbi, E. Sala, K. A. Selkoe, J. J. Stachowicz, and R. Watson. 2006. Impacts of biodiversity loss on ocean ecosystem services. Science (Washington, D.C.) 314:787-790. 
